Rapp. Grønlands geol. Unders. 106, 65-68 (1981)

\title{
THE KAP WASHINGTON GROUP VOLCANICS
}

\author{
P. E. Brown and I. Parsons
}

\section{Introduction}

The Kap Washington Group volcanic rocks outcrop on the north coast of Johannes V. Jensen Land and Lockwood $\varnothing$, where they are in thrust contact with Palaeozoic metasediments of the North Greenland fold belt. Their outcrop is limited, from west to east, to Lockwood $\varnothing$, Kap Kane, Kap Washington and Kap Cannon (fig. 21). The volcanic rocks post-date basic dykes which cut Carboniferous and Permian sediments (Håkansson et al., this report) and their age, as determined by whole rock $\mathrm{Rb}-\mathrm{Sr}$ isotopes in rhyolitic material, is $63 \mathrm{Ma}$ (Larsen et al., 1978) i.e. early Tertiary. This is somewhat younger than the late Cretaceous age established by micropalaeontological evidence (D. Batten, personal communication) from shales, found in 1980 , interbedded with the volcanics.

Preliminary field observations (Dawes \& Soper, 1973) suggested that the volcanics are calc-alkaline. Initial petrographic observations of our specimen collection have shown that the bulk of the volcanic rocks are of peralkaline type, with such characteristic members as riebeckite trachytes and riebeckite rhyolites or pantellerites. Petrographic definition of less voluminous basaltic lavas awaits further laboratory study. The presence of peralkaline rocks is significant with respect to the tectonic evolution of the Arctic Ocean.

The outcrops on Lockwood Ø, Kap Kane, Kap Washington and Kap Cannon are isolated one from another and it has not proved possible to make lithological correlations between them. The base of the volcanic succession is only seen on the west side of Lockwood $\varnothing$ and the volcanic outcrop is complicated by thrusting, but it seems that in general the outcrops are of younger rocks from west to east and will be described in that order.

\section{Lockwood $\varnothing$}

On the west side of Lockwood $\varnothing$ the base of the volcanic succession dips at angles between $50^{\circ}$ to $60^{\circ}$ to the south-east and is conformable to and, to a minor extent, interbedded with t.lack shales which contain fragmental plant debris. Unlike other shales which occur interbedded with the volcanics high in the pile, those at the base have proved unsuitable for micropalaeontological study, the material sampled being somewhat baked and fissile. Leaf fragments of archaic angiosperms are, however, present and indicate an early to middle Cretaceous age (B. Eske Koch, personal communication). The shales, with thin bedded sandstones, are at least $100 \mathrm{~m}$ thick and overlie fossiliferous Carboniferous-Permian sediments (cf. Soper et al., 1980).

The exact nature of the junction between the older sediments and the black shales beneath the volcanics is not clear on Lockwood $\varnothing$, where the exposures occur in steep cliffs. Fault movements have caused brecciation, shearing and an abundance of slickensided surfaces in all rock units in the vicinity of the junction and these movements are presumably also responsible for the absence of black shales at the north-west of the outcrop, where sheared and broken rocks at the base of the volcanic succession directly overlie Permian limestones and quartzites. Minor intrusions of dolerite are abundant in the Carboniferous, Permian and 


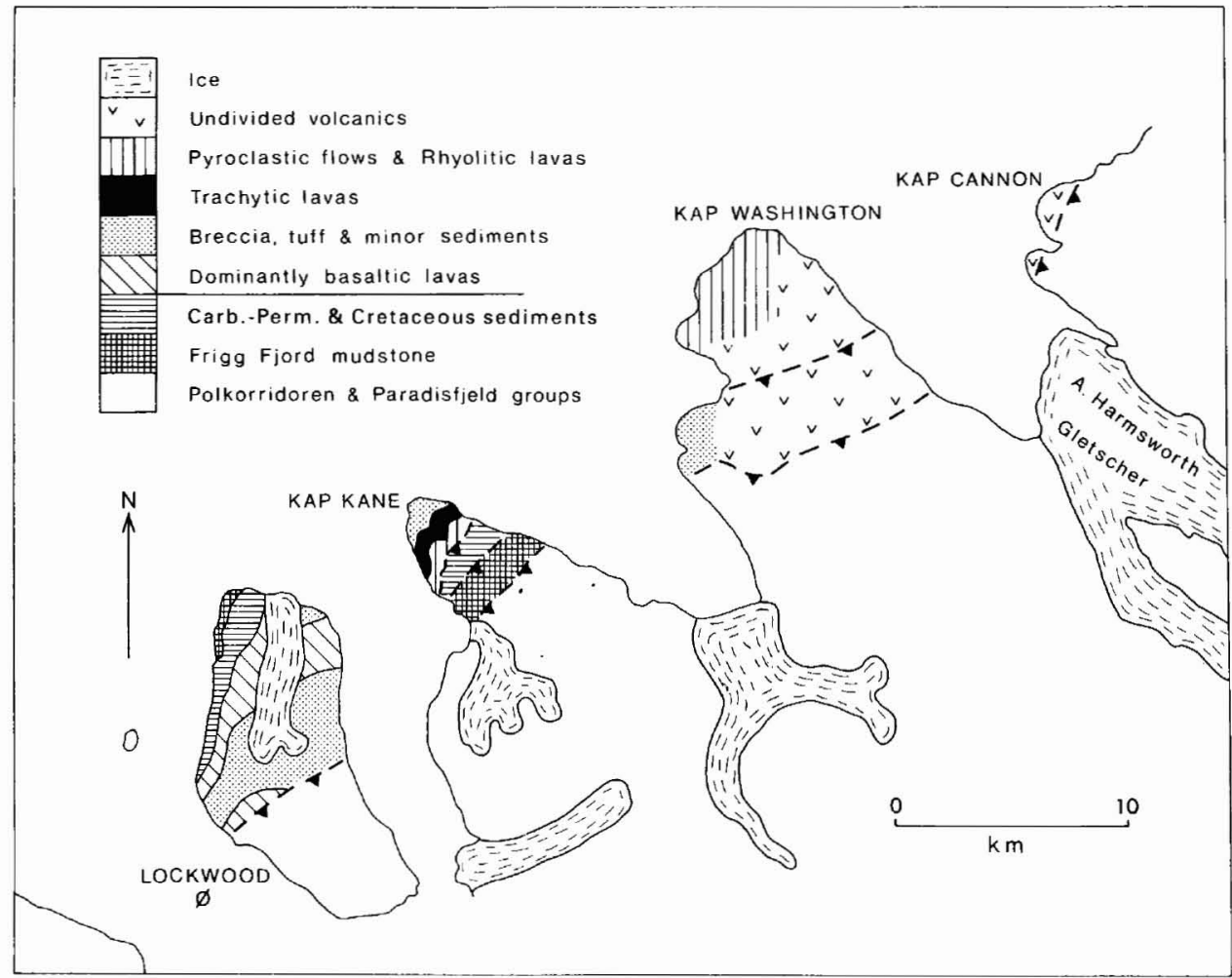

Fig. 21. Sketch map of the geological setting of the Kap Washington volcanic group.

older rocks, both on Lockwood $\varnothing$ and elsewhere in the area. Such intrusions are completely absent from the volcanic rocks but some are thought to cut the lowermost black shales beneath the volcanics.

Above the black shales the lower $900 \mathrm{~m}$ (all thicknesses approximate) of volcanics are predominantly fine grained, aphyric, basaltic lavas which have a blue colour in hand specimen. There are also minor interbedded breccias and tuffs. Similar lavas occur on the east side of Lockwood $\varnothing$ and are sparsely represented on Kap Kane. The few microscope sections available at the time of writing show that the rock type is composed essentially of plagioclase, clinopyroxene and opaque oxide; there are very rare chloritic pseudomorphs after olivine microphenocrysts. The plagioclase laths are mildly zoned with compositions around $\mathrm{Ab}_{50} \mathrm{An}_{50}$, the most calcic observed being $\mathrm{An}_{53}$. The pyroxene is pale coloured and microprobe analysis of a specimen from low down in the Lockwood $\varnothing$ succession shows it to be augite of approximate composition $\mathrm{En}_{42} \mathrm{Fs}_{17} \mathrm{Wo}_{41}$.

These lavas in some places show flow textures with strong alignment of the feldspar laths. Definition of the rock type and its variability is dependent on further petrographic and chemical data, but affinity with basaltic hawaiites is indicated.

Aphyric basaltic lavas are also found on the east side of Lockwood $\varnothing$ where they dip to the SSE at around $30^{\circ}$ and are cut by a number of dykes, presumably feeders, of the same rock type. These lavas are underlain by some $30 \mathrm{~m}$ of unfossiliferous, fissile, black shale 
which, unlike the west side of the island, overlies a further $100 \mathrm{~m}$ of purple feldsparphyric lavas of trachytic composition. The base of the succession is not seen and beneath the trachytic lavas are several hundred metres of pyroclastic rocks, predominantly breccias, but with at least one welded tuff unit.

Above the aphyric basaltic lavas the next $3 \mathrm{~km}$ thickness of the succession on Lockwood $\varnothing$ is of air-fall tuffs and breccias, much of the latter being extremely coarse. Over a large area in the south-west of the outcrop bedding is either very poor or non-existent. Within the upper parts of these pyroclastic deposits fine-bedded tuffs and volcanogenic sediments are found interbedded with black shales which contain plant debris. The plant debris is superficially similar to that in the black shales beneath the volcanic rocks and despite some baking this material has yielded pollen indicative of a late Cretaceous age (D. Batten, personal communication).

The total thickness of the volcanic rocks on Lockwood Ø is $4-5 \mathrm{~km}$. The great thickness of coarse pyroclastic rocks, and in places their lack of bedding, suggests that a volcanic centre was located in the vicinity.

\section{Kap Kane}

The volcanic rocks on Kap Kane are bounded to the south by a steep reverse fault which brings them against Permian sediments which are in turn overthrust by Palaeozoic flysch. Numerous dolerite intrusions cut all the older rocks but are not found in the volcanics. Bedding in the volcanics dips around $30^{\circ} \mathrm{SE}$ and the total thickness exposed is approximately $1.5 \mathrm{~km}$. Breccias and tuff-breccias are the dominant rocks low down in the succession with some horizons of conglomerate and sandstone. Higher up well-bedded air-fall tuffs are succeeded by feldsparphyric trachytes, of which there are some $200 \mathrm{~m}$ in flows around $20 \mathrm{~m}$ thick. These flows have a well developed trachytic texture with patches of ill-formed riebeckite and some quartz in the groundmass. Preliminary microprobe scans of the feldspar phenocrysts show them to be anorthoclase. Further thinner lavas are interbedded with occasional conglomerates and red sandstones.

Above the trachytes several flows of rhyolitic lava display flow banded and spherulitic textures. The felsic lavas are capped by a thin unit of aphyric basaltic flows which are truncated by faulting. These basaltic lavas have a well developed flow texture and are mineralogically similar to the basaltic rocks found on Lockwood Ø.

\section{Kap Washington}

The westernmost volcanic rocks on Kap Washington are isolated to the south by thrusting and from the main outcrop by glaciers. The volcanics overlie shales of unknown age which have a strong slaty cleavage. The base of the sequence is intensely sheared tuff and breccia and the junction between the sediments and volcanics is tectonised. There is some interbedded, cleaved shale within the lowest volcanics. No fossils have been found in the sediments but it is possible that these rocks are similar to the sediments beneath the volcanics on Lockwood $\emptyset$. The dip of the volcanics is around $30^{\circ}$ in a southerly direction and the thickness about $1 \mathrm{~km}$. The principle rock types are pyroclastic breccias and coarse tuffs lower down, and finely bedded, air-fall tuffs interbedded with a few lava flows towards the top. An incipient cleavage dipping more steeply than the bedding is commonly developed and becomes slaty in some of the tuffs. 
The main area of volcanic rocks forming the headland of Kap Washington is at least $3 \mathrm{~km}$ thick, but the base is not seen and the southern limit is defined by a thrust. In the lower parts pyroclastic rocks predominate and ash-flow tuffs, some with welded textures, are conspicuous. In the field great difficulty was experienced in distinguishing lavas enclosing angular lithic fragments from some of the pyroclastic deposits, a problem to be resolved by thin-section examination. Some striking examples of flow banded rhyolitic lavas contain spongy riebeckite and the evidence available suggests that the principle pyroclastic and effusive rock types on Kap Washington are peralkaline. Examination of the southernmost outcrops on the Kap Washington peninsula was terminated by bad weather and heavy snowfall, but the rocks are intensely affected by shearing associated with thrusting from the south.

\section{Kap Cannon}

Kap Cannon was visited during helicopter reconnaissance after heavy snowfall, when only the topmost point was accessible. The volcanic rocks hereabouts are affected by proximity to the Kap Cannon thrust and the rocks resemble the lower part of the main outcrop on Kap Washington with shearing accentuating the inherent difficulty of distinguishing some pyroclastic rocks from lavas.

\section{Conclusions}

A late Cretaceous age has been established for the Kap Washington volcanic rocks. The earliest oceanic magnetic anomaly recognised in the Eurasian Basin of the Arctic Ocean is number 24 (Vogt et al., 1979) which is $52 \mathrm{Ma}$ on the time-scale of Hailwood et al. (1979). The Kap Washington volcanic rocks, which predate the opening of the Eurasian Basin, are peralkaline and suggestive of crustal thinning and extension prior to separation. Significantly the volcanic rocks were preceded by intrusion of dolerite dykes which cut Carboniferous, Permian and older rocks. These dykes are part of an intense regional swarm which cuts the North Greenland fold belt described by Dawes and Soper (1979) and Higgins et al. (this report). These authors record various dyke trends, but of particular significance is the dominance of dykes with a general NW-SE trend which we have observed throughout the area immediately south of the volcanics and which are indicative of strong crustal dilation.

\section{References}

Dawes, P. R. \& Soper, N. J. 1973: Pre-Quaternary history of North Greenland. In Pitcher, M. G. (edit.) Arctic Geology. Mem. Amer. Ass. Petrol. Geol. 19, 117-134.

Dawes, P. R. \& Soper, N. J. 1979: Structural and stratigraphic framework of the North Greenland fold belt in Johannes V. Jensen Land, Peary Land. Rapp. Grønlands geol. Unders. 93, 40 pp.

Hailwood, E. A., Bock, W., Costa, L. I., Dupeable, P. A., Muller, C. \& Schnitker, D. 1979: Chronology and biostratigraphy of the Northeast Atlantic sediments, DSDP Leg 48. Initial Reports of the Deep Sea Drilling Project 48, 1119-1141.

Larsen, O., Dawes, P. R. \& Soper, N. J. 1978: Rb/Sr age of the Kap Washington Group, Peary Land, North Greenland and its geotectonic implications. Rapp. Grønlands geol. Unders. 90, 115-119.

Soper, N. J., Higgins, A. K. \& Friderichsen, J. D. 1980: The North Greenland fold belt in eastern Johannes V. Jensen Land. Rapp. Grønlands geol. Unders. 99, 89-98.

Vogt, P. R., Taylor, P. T., Kovacs, L. C. \& Johnson, G. L. 1979: Detailed aeromagnetic investigation of the Arctic Basin. J. Geophys. Res. 84, 1071-1089. 